Trakya Eğitim Dergisi

Cilt 9, Sayı 4

2019 Ek Sayı

Aralık 2019, 680-695

Geliş Tarihi: 11.12 .2018

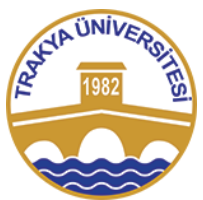

ISSN: 2630-6301
Trakya Journal of Education

Volume 9, Issue 4

2019 Additional Issue

December 2019, 680-695

DOI: $10.24315 /$ tred .494903

Yayına Kabul Tarihi: 06.12.2019

Araştırma Makalesi

\title{
The Development of an Achievement Test for the Principles and Methods of Instruction Course ${ }^{1}$
}

\author{
Ö̆̆retim İlke ve Yöntemleri Dersi için Başarı Testi Geliştirilmesi
}

\author{
Melike ÖZÜDOĞRU ${ }^{2}$, Meral AKSU ${ }^{3}$
}

\begin{abstract}
This study aimed to develop an achievement test in the Principles and Methods of Instruction Course. 14 goals were developed by following the aims of the course as determined by the Council of Higher Education. The first form of the achievement test consisted of 49 items implemented to 486 volunteer sophomore preservice teachers who took the Principles and Methods of Instruction Course in the spring semester of 2016-2017 academic year. Test Analysis Program (TAP, version 14. 7. 4) was used to examine the item discrimination indices, item difficulty indices and reliability coefficient of the achievement test. After conducting the analyses, the difficulty indices of the remaining items ranged between '.15-.74' with a mean difficulty index of .51. The item discrimination indices were between '.21-.57' with a mean difficulty index of .37 . Finally, the KR-20 value was found to be .78 .
\end{abstract}

Keywords: Achievement test, principles and methods of instruction course, item analysis.
Öz: Bu çalışmanın amacı, öğretmen adaylarının Öğretim İlke ve Yöntemleri dersindeki başarılarını belirlemek amacıyla bir başarı testi geliştirmektir. Yükseköğretim Kurulu tarafından belirlenen dersin amaçları doğrultusunda 14 hedef geliştirilmiştir. 2016-2017 eğitim-öğretim yılı bahar yarıyılında Ege Bölgesinde yer alan üniversitelerde öğrenim gören ve Öğretim İlke ve Yöntemleri dersini alan 486 gönüllü ikinci sınıf öğretmen adayına 49 maddeden oluşan başarı testinin deneme formu uygulanmıştır. Başarı testinin madde ayırt edicilik indeksi, madde güçlük indeksi ve güvenirlik katsayısını incelemek için Test Analiz Programı (TAP, 14. 7. 4) kullanılmıştır. Analiz sonrası, maddelerin güçlük indeksleri, '.15.74' arasında değişirken ortalama güçlük indeksi .51 olarak bulunmuştur. Maddelerin ayırt edicilik indeksleri ' .21-.57' arasında değişirken ortalama ayırt edicilik indeksi .37'dir. Son olarak, KR20 değeri .78 olarak bulunmuştur.

Anahtar sözcükler: Başarı testi, öğretim ilke ve yöntemleri dersi, madde analizi.

\section{UZUN ÖZ}

\section{Giriş}

Öğretmen adaylarının eğitimi ile ilgili en önemli alanlardan biri "Öğretim İlke ve Yöntemleri”" dersidir. Türkiye'de öğretmen yeterlikleri, öğretmenlerin mesleki yeterlikleri ve genel ve özel yeterlikler olmak üzere iki ayrı başlıkta düzenlenmektedir (MEB, 2006). Öğretim İlke ve Yöntemleri dersi öğretmen adaylarının öğretmenlik meslekî yeterliliklerini kazanmaları için zorunlu derslerden biridir. $\mathrm{Bu}$ ders, öğretmen adaylarının eğitim, öğretim, öğrenme ve öğretme ile ilgili temel kavramlar, öğrenme ve öğretme yaklaşımları ve öğretim yöntem ve teknikleri ile donatılmasını amaçlamaktadır. Ayrıca, bu ders, öğretmen adaylarının öğretim strateji ve yöntemlerini uygulayabilmeleri, planlı öğretim ilkelerini uygulamaya koyabilmeleri, uygun öğretim materyal ve araçlarını kullanabilmeleri, öğretmenlerin görev ve sorumluluklarının bilincine varabilmeleri ve bunların öğretmen yeterlilikleri ile ilişkilerini kavrayabilmeleri için gerekli bilgi ve beceriler kazandırmayı hedeflemektedir (YÖK, 2007).

Birçok öğretmen adayı, öğretmenlik mesleği ile ilgili yöntem ve teknikleri öğrendikleri derslerde bile problem yaşadıklarını ve derslerden etkin bir şekilde yararlanamadıklarını belirtmiştir (Dikici, Gündogdu \& Yavuzer, 2006; Kahramanoğlu, 2010; Taşkaya ve Musta, 2008). Dikici, Gündoğdu ve Yavuzer (2006), öğretmen adaylarının eğitim bilimleri derslerinden yararlanamamalarının nedenini öğretim elemanları tarafindan uygulanan öğretim yöntemleri olarak belirtmişlerdir. Benzer şekilde

\footnotetext{
${ }^{1}$ This article is a part of the doctoral dissertation of the first researcher and it was presented at the 8th International Conference of Strategic Research on Scientific Studies and Education (ICoSReSSE) 2018.

${ }^{2}$ Dr. RA, Manisa Celal Bayar University, Educational Sciences, ozudogru123@gmail.com, ORCID: https://orcid.org/00000002-7478-3576

${ }^{3}$ Prof. Dr. Meral Aksu, Middle East Technical University, Educational Sciences, aksume@metu.edu.tr, ORCID:

https://orcid.org/0000-0003-4963-39011
} 
Kahramanoğlu (2010), öğretmen adaylarının öğretmenlik mesleği ile ilgili almış oldukları derslerin içeriğinin çoğunlukla soyut olduğunu, derslerin sadece teorik olarak öğretildiğini ve gerçek sınıf uygulamaları ile yeterince ilişkili olmadığını belirtmiştir. Nitekim Öztürk (2004) öğretmenlerin en çok anlatım yöntemini ve soru-cevap tekniklerini kullandığını ve proje yöntemi gibi aktif yaklaşımlara yer veremediklerini belirtmiştir. Aydede, Çağlayan, Matyar ve Gülnaz (2006), öğretmenlerin farklı yöntem ve tekniklerin nasıl uygulanacağı konusunda yeterli bilgiye sahip olmadıklarını açıklamıştır.

Başarı testleri, öğrencilerin bir dersin içeriği hakkındaki bilgisini, anlayışını, ustalığını ve uzmanlığını değerlendirmek için kullanılan ölçme araçlarıdır (Akhter ve Bahoo, 2015). Başka bir ifadeyle, başarı testleri, öğrencilerin bir konu hakkındaki güçlü ve zayıf yönlerini teşhis etmek için kullanılır. Ayrıca, başarı testleri eğitimcilere öğrencileri farklı dersleri öğrenme yetenekleri, hazırlıklı olmaları, öğrenme güçlükleri, öğrenme ihtiyaçları ve ilgi alanlarına göre belirlemelerine yardımcı olmaktadır (Akhter ve Bahoo, 2015). Farklı derslerde ve sınıf seviyelerinde başarı testlerinin geliştirilmesini içeren birçok çalışma bulunmaktadır (Demir, Kızılay ve Bektaş, 2016, Fidan, 2013; Kara ve Çelikler, 2015; Tosun ve Taşkesenligil, 2011; Uzunoğlu-Yegül, 2014).

\section{Çalışmanın Amacı ve Önemi}

Bu çalışmanın amacı, öğretmen adaylarının Öğretim İlke ve Yöntemleri dersindeki başarılarını belirlemek amacıyla bir başarı testi geliştirmektir. Öğrencilerin başarısı, öğretimin etkililiğini belirleyen önemli değişkenlerden biridir. Bu bağlamda, öğrencilerin başarılarının incelenmesi, hizmet öncesi öğretmen yetiştirme eğitimine katkıda bulunacağı düşünülmektedir.

Ayrıca, literatürde bazı terimlerin kullanımı hakkında karışıklıklar vardır. Öğretmen adayları için en önemli sınavlardan biri olan KPSS'de (Kamu Personel Seçme Sınavı) aynı kavram için farklı terimler kullanılmaktadır. Örneğin, KPSS-2013'te 15. soruda "hangi yöntem veya teknik uygulandı?" sorusu sorulmuştur. Seçenekler 'soru ve cevap', 'çember', 'forum', 'açık oturum' ve 'beyin firtınasıdır' ki aslında tüm seçenekler birer öğretim tekniğidir. Bunlara ek olarak, KPSS-2014'te 13. soru "Beyin fırtınas1 yönteminin veya tekniğinin kullanılması aşağıda belirtilen içeriklerin hangisinin öğretilmesinde uygun değildir?" şeklinde sorulmuştur. Yine öğretmen adayları beyin firtınasının yöntem mi teknik mi olduğu ile ilgili benzer bir ikilemle karşılaşmaktadır. Aynı sorunlar KPSS-2012'de (4. Soruda), KPSS-2015'te (9. ve 11. sorular), KPSS-2016'da (7. ve 12. sorular) ve son olarak KPSS-2017'de (10. soru) belirtilen sorularda da görülebilir. Dolayısıyla, ders anlatımında ve kullanılan ölçme araçlarında yaklaşım, strateji, yöntem ve teknikler arasında ayrım yapmak ve uygun terimi kullanmak da önemlidir. Bu nedenle, öğretmen adaylarının teorik olarak öğrendiklerini gelecekteki mesleklerinde uygulamalarına yardımcı olmak için Öğretim İlke ve Yöntemleri dersi ile ilgili bilgi düzeylerini ve kavram yanılgılarını belirlemek için bir başarı testine ihtiyaç duyulmaktadır.

\section{Yöntem}

$\mathrm{Bu}$ çalışma, tarama türündedir. Nicel araştırma türlerinden olan tarama araştırmaları, araştırmacıların, önceden belirlenmiş bir örneklemin sadece belirli bir zaman diliminde görüşlerini, davranışlarını veya özelliklerini belirlemeleri için uygulanmaktadır (Fraenkel \& Wallen, 2009; Creswell, 2012). Bu çalışmada, 49 maddeden oluşan başarı testinin pilot formu 2016-2017 eğitim-öğretim yılı bahar yarıyılında Öğretim İlke ve Yöntemleri dersini alan 486 öğrenciye uygulanmıştır. Çalışmanın katılımcıları Uşak, Ege ve Manisa Celal Bayar Üniversitesi'nde öğrenim gören ve testi cevaplamaya gönüllü olan ikinci sınıf öğretmen adaylarıdır. Araştırmada cevaplanan 486 başarı testi arasından 33’ü üçten fazla soru yanıtsız bırakıldığı için analizden çıkarılmıştır. Analizler 453 öğrenci üzerinden yapılmıştır. Başarı testini geliştirmeden önce, her bir maddenin belirli bir öğrenme çıktısını ölçebilmesi için Öğretim İlke ve Yöntemleri dersinin hedefleri belirlenmiştir. Yükseköğretim Kurulunca belirlenen Öğretim İlke ve Yöntemleri dersinin amaçları doğrultusunda 14 hedef belirlenmiştir. Hedefler belirlendikten sonra, hedeflerin Öğretim İlke ve Yöntemleri dersinin içeriğini kapsadığını doğrulamak ve kapsam geçerliliğini sağlamak için belirtke tablosu hazırlanmıştır. 
Öğretim İlke ve Yöntemleri dersi başarı testinin içeriği aşağıdaki konulardan oluşmaktadır: Temel eğitim kavramları (eğitim, öğretim, öğrenme, program vb.), eğitimin amaçları ve hedefleri (eğitimde amaç ve hedeflerin belirlenmesi, hedef türleri, hedeflerin sinıflandırılması ve Bloom taksonomisi), öğretimin planlanması (plan çeşitleri, planlamanın önemi), öğretim kuram ve modelleri (Yapılandırmacılık, Gagne'nin öğrenme ve öğretme kuramı, tam öğrenme, Keller'in bireyselleştirilmiş öğretim modeli, Carroll'un okulda öğretim modeli) öğretim stratejileri (sunuş yoluyla öğretim, buluş yoluyla öğretim, araştırma ve inceleme yoluyla öğretim ve işbirlikli öğrenme), öğretim yöntemleri (anlatım, tartışma, örnek olay, proje temelli öğrenme, gösterip yaptırma, problem temelli öğrenme), öğretim teknikleri (soru-cevap, beyin firtınası, istasyon, balık kılçığı, altı şapkalı düşünme gibi farklı teknikler).

Başarı testinin maddeleri Bloom Taksonomisinin bilişsel alanına dayanmaktadır. Anderson vd. (2010) göre, herhangi bir davranış ortaya çıkması için, ona yol açan ön bilgi de öğrenilmelidir. Bu nedenle, başarı testi için hazırlanan maddeler Bloom Taksonomisinin bilgi, kavrama ve uygulama aşamalarına ilişkindir. Başarı testinin geçerliliğini sağlamak için hedefler ve ilgili sorular Ege, Hacettepe, Iowa State, ve Orta Doğu Teknik Üniversiteleri Eğitim Programları ve Öğretim Bölümünde görevli yedi uzman (bir profesör, iki doçent ve dört yardımcı doçent) tarafından incelenmiştir. Uzmanlardan soruların açıklı̆ıını, anlaşılırlığını, hazırlanan soruların konuları temsil etme gücünü ve testin tasarımının uygunluğunu kontrol etmeleri istenmiş̧ir. Bu çalışmada, madde güçlük indeksleri, madde ayırt edicilik indeksleri ve başarı testinin güvenirlik katsayısını incelemek için Test Analiz Programı (TAP, versiyon 14. 7. 4) kullanılmıştır. Öncelikle test maddelerinin güçlük indeksleri incelenmiştir. Ne çok zor ne de çok kolay olan bir madde iyi bir madde olarak değerlendirilmektedir (Ozcelik, 2011). Diğer bir ifadeyle, '0.20 - 0.80' arasında güçlüğe sahip olan, orta güçlük derecesindeki maddelerin başarı testine alınması tavsiye edilmektedir (Turgut ve Baykul, 2011).

Madde güçlük indeksinden sonra, her bir maddenin ayırt edicilik indeksleri incelenmiştir. Düşük ayırt edicilik indeksine sahip olan maddeler ya çok zor ya da çok kolay maddelerdir. Negatif ayırt edicilik indeksleri, başarılı öğrencilerin soruya yanlış cevap verdiğini göstermektedir ve bu maddeler testten çıkarılmalıdır (Büyüköztürk, Kılıç Çakmak, Akgün, Karadeniz \& Demirel, 2010). Madde ayırt edicilik indeksleri .20'nin üzerinde olan test maddelerinin, akademik başarı testlerinde yer almalarının uygun olduğu belirtilmektedir (Özçelik, 2011; Turgut ve Baykul, 2011). Test maddelerinin analizinde bir diğer önemli faktör ise güvenilirlik katsayısıdır. Başarı testinin iç tutarlılığını belirlemek için Kuder ve Richardson-20 (KR-20) katsayısı kullanılmıştır. KR-20 değerleri 0 ile 1 arasında değişir. Değer 1'e ne kadar yakın olursa iç tutarlılık o kadar iyidir. Fraenkel ve Wallen'e (2008) göre, testin güvenirlik katsayısının 0.70 veya üzerinde olmas1, testin güvenilir olduğunu göstermektedir.

\section{Bulgular}

Yapılan madde analizleri sonrasında, düşük ayırt edicilik indeksine sahip dokuz madde testten çıkarılmıştır. Kalan test 40 maddeden oluşmaktadır. Maddelerin güçlük indeksleri, '.15-.74' arasında değişirken ortalama güçlük indeksi .51 'dir. Maddelerin ayırt edicilik indeksleri '.21-.57' arasında değişmektedir ve ortalama madde ayırt edicilik indeksi .37'dir. Son olarak, KR-20 değeri .78 olarak bulunmuştur.

\section{Tartışma ve Sonuç}

Başarı testinin nihai formu, uygulaması 40-45 dakika süren ve kolayca puanlanabilen bu nedenle de kullanıcı dostu bir ölçme ve değerlendirme aracıdır. Başarı testi, YÖK (2007) tarafindan belirtilen Öğretim İlke ve Yöntemleri dersinin tüm hedeflerini içerdiği için, dönem sonunda değerlendirme amaçlı kullanılabilir. Test, aynı zamanda, hizmet öncesi öğretmen adaylarının bilgi düzeylerini ve bu ders hakkındaki kavram yanılgılarını incelemek için iyi bir ölçme ve değerlendirme aracıdır. Ayrıca, bu başarı testi, Öğretim İlke ve Yöntemleri dersi ile ilgili bilimsel çalışmalar yürüten araştırmacılar tarafından kendileri veya diğer araştırmacılar tarafından geliştirilen başarı testlerinin ölçüt geçerliliğini kontrol etmek için de kullanılabilir.

\section{INTRODUCTION}

Since the time teacher education emerged, it has been critiqued, studied, rethought and reformed (Cochran-Smith, 2004). Teacher training programs educate pre-service teachers, who are getting prepared 
to apply the content knowledge, skills and abilities related to the teaching profession in real classroom environments (Chiatula, 2015). In other words, pre-service teachers are getting prepared to apply what they have learned in their university-based courses to classroom practices. Although pre-service teachers take higher grades and even earn honors, they still find it difficult to connect what they have learned during training to actual classroom practices when they enter the world of the public schools (Chiatula, 2015; Eret, 2013).

In Turkey, it has been observed that faculties are not adequate in teaching different methods (Taskaya, \& Musta, 2008). Many pre-service teachers indicated that even in the courses that they learned about teaching and learning, they experienced problems and could not benefit from the courses efficiently (Dikici, Gündogdu \& Yavuzer, 2006; Kahramanoglu, 2010; Taskaya, \& Musta, 2008). Dikici, Gundogdu, and Yavuzer (2006) reported the reason for pre-service teachers' not being able to benefit from the educational sciences courses as the teaching methods implemented by their instructors. Similarly, Kahramanoglu (2010) indicated that the content of the courses pre-service teachers had taken about teaching profession was mostly abstract, and the courses were taught only theoretically and were not sufficiently associated with real classroom applications. Hence, Ozturk (2004) stated that teachers mostly used lecturing method and question-answer techniques and they expressed their inability to apply the project method. In addition, in the study conducted by Eret (2013), pre-service teachers revealed that their instructors included ineffective, traditional, or teacher-centered methods and techniques. They mostly used PowerPoint presentations, even did not lecture but left the lecturing to pre-service teachers, did not include discussions and did not use technological materials in courses. Moreover, even though the instructors of pre-service teachers told them to accept constructivist approach and conduct courses accordingly, they did not follow constructivist approach, they only lectured. It can be said that pre-service teachers were taught through PowerPoint presentations and lecturing in which the topics of course were not sufficiently associated with real classroom applications. For this reason, it can be said that they could not benefit from the courses efficiently and as also stated by Aydede, Caglayan, Matyar, and Gulnaz (2006) they do not have enough knowledge about how to apply these methods and techniques.

In Turkey, the proficiencies of teachers are organized in two separate titles as teacher professional competencies and general and specific competencies by the Ministry of Education General Directorate of Teacher Development (MEB, 2006). The Principles and Methods of Instruction (PMI) course is one of the compulsory courses for pre-service teachers' gaining the professional competencies of teachers. This course aims to equip pre-service teachers with the knowledge of basic concepts related to education and instruction, learning and teaching, teaching-learning theories, approaches, methods and techniques. Also, this course aims to provide pre-service teachers with knowledge and skills to implement teaching strategies, methods, comprehend and put principles of planned instruction into practice, use suitable teaching materials and tools, become aware of teachers' duties and responsibilities and to comprehend relations of these with teacher qualifications (Higher Education Council [Yüksek Ögrretim Kurumu], 2007).

In addition, the percentage effect of the PMI course among the Educational Sciences courses in the Public Personnel Selection Examination (KPSS) which is applied to measure the competencies of teachers about the teaching profession is $26 \%$ (Pegem Academy, 2019). This exam is also important for pre-service teachers because their appointment to state schools depends to a large extent on the scores they obtained from this KPSS. Nevertheless, it was observed that the tests which were implemented in the faculties of education to determine the competence of pre-service teachers about the PMI course are generally prepared by the instructors. It can be seen that the pre-service teachers' preparation for KPSS or similar standard proficiency exams with such tests is limited. For this reason, it is thought that there is a need for standard achievement tests in teacher training classes to measure objectively the competences of pre-service teachers related to the PMI course.

Achievement tests are measurement tools which are used to evaluate the knowledge, understanding, mastery and expertise of students on specific contents of a course (Akhter \& Bahoo, 2015). In other words, they are used to diagnose the strengths and weaknesses of learners about content. Also, achievement tests help educators to classify students according to their learning abilities, learning readiness, learning difficulties, learning needs and areas of interest (Akhter \& Bahoo, 2015). Yüksel (2013) stated that the students who were successful in the exams conducted in faculties were also successful in the central exams. In other words, it can be said that exams can distinguish students with insufficient knowledge.

There are many studies included the development of achievement tests in different topics, courses and grade levels such as number domain of mathematics for elementary school students (Fidan, 2013); solutions and their physical properties (Tosun \& Taşkesenligil, 2011); constructivism for pre-service music 
teachers (Uzunoglu-Yegül, 2014); matter changing unit for secondary school fifth grade students (Kara \& Çelikler, 2015); and solutions concept (Demir, Kızllay \& Bektaş, 2016).

The achievement test developed by Tosun and Taşkesenligil (2011) included 31 items and it was implemented to 160 pre-service teachers enrolled in the chemistry teaching and elementary science teaching departments. The results of item analyses indicated that the average difficulty index of the test was .41 and the test-discrimination index was .40. The reliability of the achievement test was found .77. Fidan (2013) conducted the pilot implementation of the achievement tests for $1-4^{\text {th }}$-grade levels with around 300 students. KR-20 reliability coefficients for each grade levels were over .80 . The mean difficulty of the $1-4^{\text {th }}$-grade tests was found as .79, .74, .69 and .59, respectively. Final forms of the achievement tests consisted of 13, 15, 16 and 24 items, respectively. The achievement test developed by Uzunoglu-Yegül (2014) examined primary and secondary school music curricula, teacher guide books, researches about constructivist approach and questions which were asked in the Public Personnel Selection Examination (KPSS) preparation books during the development process of an achievement test. It included 50 multiple-choice questions and after item analyses, the internal consistency coefficient was determined as $\alpha=.85$, item difficulty and discrimination values were found very close to .30 . The achievement test developed by Kara and Çelikler (2015) included 48 questions. For the content validity of the test, two experts from the chemistry department and two primary science teachers examined the test. After taking expert opinion, the test was applied to $3546^{\text {th }}$ grade students. After item analyses, 16 items were excluded from the test because their item discrimination values were below .30. Finally, the average difficulty of the test was calculated to be .38 , the average discrimination index of the test was being calculated to be .38 and the KR-20 reliability coefficient was estimated to be .76. The achievement test developed by Demir, Kızılay, and Bektaş (2016) was applied to $1007^{\text {th }}$ grade students in the 2012-2013 academic year. The reliability coefficient of the achievement test was .74, the average discrimination index value was .49 and the average difficulty index was .58. For criterion validity, the Pearson correlation coefficient was found high.

As was explained in the literature there are many studies which included the development of achievement tests in different courses and grade levels, however, it was noticed that there are few achievement test development studies about the educational sciences courses which are quite important for pre-service teachers. When the previous studies about developing an achievement test in the PMI course were examined, it was noteworthy that researchers included achievement besides various variables such as reflective thinking skills, critical thinking skills, democratic attitudes, epistemological belief, metacognitive awareness, and learning motives in the master's thesis and doctoral dissertations carried out in the PMI course. In these theses, it was stated that achievement tests were developed for some of the topics of the course or all subjects of the PMI course (Firat-Durdukoca, 2013; Gültekin, 2016; Polat, 2016; Tican, 2013; Türkyılmaz, 2016; Yünkül, 2014).

The achievement test which was developed by Tican (2013) included 44 multiple-choice questions, one matching type question and five open-ended questions. The content of the achievement test included six methods involved in the PMI course. During the development of sample achievement tests both expert and student opinions were obtained. The KR-20 reliability of the achievement test was found .80 . The difficulty indices of items ranged between '.11-.91' with a mean difficulty index of .59. In the study conducted by Firat-Durdukoca (2013) an 89-item sample PMI course achievement test was prepared but eight items were found unsuitable after taking expert opinions. The test was implemented to 316 pre-service teachers. After item analyses, the final form included 48 items by excluding 33 items from the test because of low item discrimination indices. 21 items had difficulty indices lower than .50 and 22 items had difficulty indices over .50 and five items had difficulty indices of .50. While Spearman-Brown reliability was .91, the KR-20 reliability of the achievement test was found .92. In addition to these Cardak \& Selvi (2018) developed 39-items multiple-choice achievement test and conducted two separate pilot applications for item analyses. While 381 pre-service teachers participated in the first applications, 113 pre-service teachers participated in the second application. The final test included 21 items. The KR-20 reliability for the test was .83 , the average difficulty level of the test was .49 .

Although there are few achievement test development studies, different terms such as approach, strategy, method and technique were used by researchers as also stated by Tan, Erciyeş, Güven, and Kıliç (2007). While the term 'teaching method' refers to the general principles, pedagogy and management strategies used for classroom instruction, a 'teaching technique' is a precise strategy that is designed to reach the goals of instruction. A technique can be in the form of an exercise or just any activity that is based on a proper method. For instance, while 'discussion' is a method, 'panel', 'forum', 'hoop', 'forum', 'opensession' and 'brainstorming' are techniques that are based on a proper method to realize the aims of 
instruction. Besides some of the test development studies, in the KPSS (Public Personnel Selection Examination), two different terms for the same concept were used. For example, the fourth question asked in KPSS-2012 was "which method or technique was applied?" Similarly, in KPSS-2013 the $15^{\text {th }}$ question was "which method or technique was applied?" The options were 'question and answer', 'hoop', 'forum', 'open-session' and 'brainstorming' which are techniques. In addition to these, in KPSS-2014 the $13^{\text {th }}$ question was "while teaching the contents stated below the use of brainstorming method or technique is not appropriate?" Again the pre-service teachers face the same dilemma whether the brainstorming is a method or technique. The same issues can be seen in the questions asked in KPSS-2015 ( th $^{\text {th }}$ and $11^{\text {th }}$ questions), $\operatorname{KPSS} 2016\left(7^{\text {th }}\right.$ and $12^{\text {th }}$ questions) and finally, KPSS $2017\left(10^{\text {th }}\right.$ question $)$. Hence, it was thought important for pre-service teachers and all stakeholders to discriminate between approaches, methods and techniques, learn and use them properly.

\section{The aim and the Significance of the Study}

This study aimed to develop an achievement test in the PMI course. Achievement of students is one of the important variables that determine the effectiveness of instruction. In this regard, the examination of pre-service teachers' achievement is thought to contribute pre-service teacher training since there is not enough satisfaction with the findings of research studies to be able to say exactly about the contribution of theoretical learning of the PMI course to practice in their future professions. Also, this test can serve as a tool to measure whether pre-service teachers know and discriminate the concepts such as theory, approach, strategy, methods and techniques or not. Moreover, it can ensure that teacher education programs are improved in terms of these competencies. The test can also be implemented by academicians in experimental studies related to the PMI course as a measurement tool to assess pre-service teachers' knowledge level and misconceptions about this course or researchers can examine it as a sample test for new tests they will develop. In addition, this achievement test can be used by researchers conducting studies about the PMI course to check the criterion validity of another achievement test developed by them. Moreover, all stakeholders including people responsible to prepare questions about KPSS might benefit from the results of this study.

\section{METHOD}

In this part, research design participants of the study, data collection instrument, data collection procedures and data analysis were explained.

\section{Research Design}

This study was based on survey research design. Survey research designs are procedures in quantitative research in which researchers administer a survey to a sample which has been drawn from a pre-determined population at just one point in time (Fraenkel \& Wallen, 2009). In this way, they describe the attitudes, opinions, behaviors, or characteristics of the population (Creswell, 2012).

\section{Subjects of the Study}

In the current study, the pilot form of the achievement test including 49 items was implemented to 486 sophomore pre-service teachers who took the PMI course in the spring semester of the 2016-2017 academic year. The participants of the study were pre-service teachers who were studying at Uşak, Ege and Manisa Celal Bayar Universities and volunteer to take part in the study. Among the 486 pre-service teachers, who answered the test, the results of 453 students were included and 33 students were removed from the analyses because of more than three unanswered questions.

\section{Data Collection Instruments and Procedures}

In the current study, data were collected through PMI course achievement test. This study was conducted in the spring semester of 2016-2017 academic year. Before developing the achievement test, goals of PMI Course were determined so that each items would evaluate a particular learning outcome. 14 goals were developed by following the aims of the PMI Course as determined by Higher Education Council (Yüksek Öğretim Kurumu, 2007).

After determining the goals of the course, the objectives relevant to the goals of the course were determined. For instance, by basing on the first goal "Students will be able to understand the basic concepts related to education", the objective was written as 'Students match specific concepts with proper instances'. Also, by basing on the second goal 'Students will be able to use appropriate teaching principles in different teaching-learning situations' two objectives were written. They were: (1) Students will be able to select the teaching principle that should be used in a given situation and (2) Students select which teaching principle does not fit to a given situation. As for the third goal 'Students will be able to understand the properties of 
objectives', the objective was written as 'Students distinguish the expressions that do not comply with the objective writing principles.' In addition, for the eight goal 'Students will be able to use appropriate theories, models and approaches for different teaching-learning conditions', two objectives were written. They were: (1) Students select appropriate theories and approaches for a given situation and (2) Students determine methods and techniques that are relevant to teaching-learning theories and approaches. For this reason, the table of specifications was prepared to confirm that the objectives and the related items covered the content of PMI course. Moreover, the table of specifications was also prepared to ensure the content validity. The distribution of test items across the goals of PMI course was presented in Table 1.

Table 1. Distribution of test Items across the Topics and Goals of Principles and Methods of Instruction Course

\begin{tabular}{|c|c|c|}
\hline The topics of the Course & Goals of the Course & $\begin{array}{l}\text { Item Numbers in } \\
\text { the Pilot Test }\end{array}$ \\
\hline Basic concepts of education & $\begin{array}{l}\text { 1. Students will be able to understand the } \\
\text { basic concepts related to education. }\end{array}$ & $1,2,45,46,47,48,49$ \\
\hline Teaching principles & $\begin{array}{l}\text { 2. Students will be able to use appropriate } \\
\text { teaching principles in different teaching- } \\
\text { learning situations. }\end{array}$ & $3,4,5,6$ \\
\hline \multirow[t]{2}{*}{$\begin{array}{l}\text { The goals and objectives of } \\
\text { education }\end{array}$} & $\begin{array}{l}\text { 3. Students will be able to understand the } \\
\text { properties of objectives. }\end{array}$ & $7,8,9,10$ \\
\hline & $\begin{array}{l}\text { 4. Students will be able to use different types } \\
\text { of objectives in accordance with teaching- } \\
\text { learning situations. }\end{array}$ & $11,12,13$ \\
\hline Planning of Instruction & $\begin{array}{l}\text { 5. Students will be able to understand the } \\
\text { properties of teaching plans. }\end{array}$ & 14,15 \\
\hline $\begin{array}{l}\text { Teaching-learning theories, } \\
\text { approaches, models, strategies, } \\
\text { methods, and techniques. }\end{array}$ & $\begin{array}{l}\text { 6. Students will be able to know the } \\
\text { properties of teaching-learning theories, } \\
\text { approaches, models, strategies, methods and } \\
\text { techniques. }\end{array}$ & $16,18,19,20,21$ \\
\hline Teaching theories and models & $\begin{array}{l}\text { 7. Students will be able to understand the } \\
\text { properties of teaching-learning theories, } \\
\text { models and approaches. }\end{array}$ & $22,23,24$ \\
\hline Teaching theories and models & $\begin{array}{l}\text { 8. Students will be able to use appropriate } \\
\text { theories, models and approaches for } \\
\text { different teaching-learning conditions. }\end{array}$ & 25 \\
\hline \multirow[t]{2}{*}{ Teaching strategies } & $\begin{array}{l}\text { 9. Students will be able to understand the } \\
\text { properties of teaching strategies. }\end{array}$ & 26,27 \\
\hline & $\begin{array}{l}\text { 10. Students will be able to use appropriate } \\
\text { teaching strategies for different teaching- } \\
\text { learning conditions. }\end{array}$ & 28 \\
\hline \multirow[t]{2}{*}{ Teaching methods } & $\begin{array}{l}\text { 11. Students will be able to understand } \\
\text { teaching methods. }\end{array}$ & $17,29,30,31,32$ \\
\hline & $\begin{array}{l}\text { 12. Students will be able to use appropriate } \\
\text { teaching methods for different teaching- } \\
\text { learning conditions. }\end{array}$ & $33,34,35$ \\
\hline Teaching techniques & $\begin{array}{l}\text { 13. Students will be able to understand the } \\
\text { properties of teaching techniques. }\end{array}$ & $36,37,38,39,40$ \\
\hline Teaching strategies and techniques & $\begin{array}{l}\text { 14. Students will be able to use appropriate } \\
\text { teaching techniques for different teaching- } \\
\text { learning conditions. }\end{array}$ & $41,42,44$ \\
\hline
\end{tabular}

The content of the Principles and Methods of Instruction course achievement test included the following topics: Basic concepts of education (education, teaching, learning, program etc.), goals and objectives of education (determination of goals and objectives in education, types of objectives, the classification of objectives and Bloom's taxonomy), planning of instruction (types of plans, importance of planning, etc.), teaching theories and models (Gagne's theory on learning and instruction, Mastery learning, Keller's individualized instruction, Carroll's model of school learning, Bloom's mastery learning, constructivism, multiple intelligence theory etc.), teaching strategies (teaching through presentation, discovery learning and teaching through research and investigation and cooperative learning), methods of 
teaching (lecturing, discussion, case study, demonstration, project-based learning, problem based learning etc.), teaching techniques (question and answer, brainstorming, station, fishbone, six hat techniques etc.).

The development of the test items was based on the cognitive domain of Bloom's Taxonomy. According to Anderson et al. (2010), in order for any behavior to occur, the prerequisite knowledge leading to it should also be learned. Hence, the questions were related to knowledge, comprehension and application levels of Blooms' Taxonomy.

While developing the achievement test, different sources such as PMI course books, related literature and instruments developed by other researchers were examined. Since more than one objective was written related to some topics, more than three questions were written for each topics except planning of instruction topic (Turgut \& Baykul, 2011; Ozcelik, 2010).

In order to establish face validity of the AT, the objectives and related questions were checked by seven experts (one professor, two associate professors, and four assistant professors) in Curriculum and Instruction Department of Ege University, Hacettepe University, Iowa State University and Middle East Technical University as stated by Turgut \& Baykul (2011). They were asked to check for the clarity of questions, representativeness of content by the selected items and appropriateness of the design of the instrument. One of the experts suggested that some items need to be written shorter. Moreover, another expert suggested that the length of distractors need to be the same for the item related to mastery learning. The other expert suggested replacing one of the distractors for the items four and 33 because they seemed too strong. Moreover, many experts warned to be careful and check if the options contained any hints which may help responders answer the other questions. Furthermore, one of the experts suggested restating the distractors of item 26, because the option B and E were very close in meaning, which could result in the elimination of each other. Hence, the item $\mathrm{E}$ was restated. Also, one of the experts suggested stating the objectives by using the same type of verbs such as 'finds, takes, improves, proposes, eliminates', instead of using different type of words such as "finds, getting, improves, proposes, elimination (bulur, almak, geliştirmek, ileri sürer, giderilmesi)". Suggestions of experts were taken into consideration while revising the instrument.

After taking the opinions of experts, the test was administered to five pre-service teachers to examine if any statements could be misunderstood and to check the optimal administration time. They indicated the clarity of questions and the adequacy of test duration. On the other hand, some of the pre-service teachers stated that they did not learn some of the techniques that were asked in the test. Hence, they stated that the test was a little harder than they were used to. The reason for this case might be that since there are dozens of different teaching techniques in the literature, students might have taught different techniques by their instructors. For this reason, the sample achievement test was reviewed and the techniques pointed by these five pre-service teachers were replaced with the distractors which are mostly asked in central exams.

The pilot form of the achievement test which consisted of 49 items was applied to 486 sophomore students who took the PMI Course at the spring semester of 2016-2017 academic year. The applications started in May and were completed in June. Students were given enough time to answer the questions.

Firstly, the item difficulty index was examined. An item which is neither too difficult nor too easy is evaluated to be a good question. In other words, test items having moderate difficulty and having indices between ' $0.20-0.80$ ' are recommended to be included in achievement tests (Turgut \& Baykul, 2011). The difficulty indices of test items can be categorized as follow (Ozcelik, 2011):

- Items having difficulty indices between ".00 - .19" are referred to as "very difficult"

- Items having difficulty indices between ".20-.39" are referred to as "difficult"

- Items having difficulty indices between ". $40-.59$ " are referred to as "moderate"

- Items having difficulty indices between ".60 - .79" are referred to as "easy"

- Items having difficulty indices between ". $80-1.00$ " are referred to as "very easy".

After the item difficulty index, the item discrimination index was examined. The items which have low discrimination indices are either very difficult or very easy (Turgut \& Baykul, 2011). Negative discrimination indices indicate that participants who know the topic answer the items wrong (Büyüköztürk, et al., 2010). Items having negative discrimination should be removed from the test. Test items having discrimination indices above .20 are normally considered to be appropriate for the application of academic achievement tests (Ozcelik, 2011; Turgut \& Baykul, 2011).

Another important factor for the item analysis of an achievement test is reliability coefficient. The Kuder and Richardson-20 (KR-20) formula for determining internal consistency of achievement test was used. The values of KR-20 can range between 0 and 1 . The closer the value to 1 , the better the internal 
consistency. According to Fraenkel and Wallen (2008), a reliability coefficient of .70 or above indicates that the test is reliable enough that can be used as a research tool.

\section{Data Analysis}

In the current study, the item Point Biserial discrimination indices, item difficulty indices and reliability coefficient of the achievement test were calculated by using Test Analysis Program (TAP, version 14. 7. 4) and alpha level was determined as .05 for analysis.

\section{RESULTS}

According to the item difficulty and item discrimination indices analyses, items S1, S3, S7, S8 and S9 which were indicated by the TAP as having low item discrimination indices and either very high item difficulty or very low item difficulty indices were omitted from the test. By running the program again, the items S11, S17, and S21 were removed from the AT because of having a discrimination index less than .20. This means that these items have a very low ability to discriminate students who know the content from those who do not. For item 20 (S20), it had item discriminating index '.19' and item difficulty index '.37'. However, by asking the opinions of experts and checking the number of remaining items about the same goal, it was also removed from the test. Moreover, items S2, S25 and S33 were revised in terms of distractors. The item difficulty and discrimination indices were shown in Table 2 before removing items.

Table 2. Item Difficulty and Item Discrimination Indices of the Sample Test

\begin{tabular}{|c|c|c|c|c|c|}
\hline Items & $\begin{array}{l}\text { Item Difficulty } \\
\text { Index }\end{array}$ & $\begin{array}{l}\text { Item Discrimination } \\
\text { Index }\end{array}$ & Items & $\begin{array}{l}\text { Item Difficulty } \\
\text { Index }\end{array}$ & $\begin{array}{l}\text { Item Discrimination } \\
\text { Index }\end{array}$ \\
\hline S1 & .56 & .09 & S26 & .69 & .36 \\
\hline S2 & .31 & .31 & S27 & .54 & .34 \\
\hline S3 & .65 & .18 & S28 & .45 & .30 \\
\hline S4 & .87 & .16 & S29 & .52 & .55 \\
\hline S5 & .44 & .28 & S30 & .59 & .48 \\
\hline S6 & .64 & .43 & S31 & .38 & .47 \\
\hline S7 & .13 & .04 & S32 & .54 & .31 \\
\hline S8 & .23 & .01 & S33 & .34 & .20 \\
\hline S9 & .10 & .13 & S34 & .75 & .38 \\
\hline S10 & .45 & .41 & S35 & .58 & .36 \\
\hline S11 & .77 & .18 & S36 & .31 & .24 \\
\hline S12 & .70 & .39 & S37 & .74 & .46 \\
\hline S13 & .24 & .28 & S38 & .72 & .37 \\
\hline S14 & .67 & .22 & S39 & .72 & .24 \\
\hline S15 & .65 & .30 & S40 & .47 & .43 \\
\hline S16 & .67 & .50 & S41 & .50 & .42 \\
\hline S17 & .91 & .15 & S42 & .62 & .45 \\
\hline S18 & .65 & .42 & S43 & .29 & .23 \\
\hline S19 & .68 & .54 & S44 & .24 & .23 \\
\hline S20 & .37 & .19 & S45 & .45 & .31 \\
\hline S21 & .91 & .16 & S46 & .21 & .19 \\
\hline S22 & .31 & .25 & S47 & .60 & .29 \\
\hline S23 & .42 & .47 & S48 & .47 & .37 \\
\hline S24 & .31 & .28 & S49 & .15 & .22 \\
\hline S25 & .45 & .37 & & & \\
\hline
\end{tabular}


The item difficulty and discrimination indices of the sample achievement test were shown in Table 3 after removing some items. As indicated in Table 3, after removing nine items from the test, the discrimination indices were between '.21-.57' with a mean difficulty index of 0.37 . The KR-20 value was found to be 0.77 before removing nine items but it became .78 after their removal. In addition to these, the difficulty indices of the remaining items ranged between '. $15-.74$ ' with a mean difficulty index of 0.51 .

Table 3. Item Difficulty, Item Discrimination Indices and Item Numbers in the Final Form

\begin{tabular}{llllllll}
\hline & S & & & & \\
S2 & S29 & .31 & .29 & $\mathrm{~S} 30$ & $\mathrm{~S} 15$ & .59 & 0.56 \\
$\mathrm{~S} 4$ & $\mathrm{~S} 1$ & .87 & .21 & $\mathrm{~S} 31$ & $\mathrm{~S} 27$ & .38 & 0.51 \\
$\mathrm{~S} 5$ & $\mathrm{~S} 25$ & .44 & .31 & $\mathrm{~S} 32$ & $\mathrm{~S} 18$ & .54 & 0.32 \\
$\mathrm{~S} 6$ & $\mathrm{~S} 13$ & .64 & .46 & $\mathrm{~S} 33$ & $\mathrm{~S} 28$ & .34 & 0.23 \\
$\mathrm{~S} 10$ & $\mathrm{~S} 22$ & .45 & .48 & $\mathrm{~S} 34$ & $\mathrm{~S} 2$ & .75 & 0.44 \\
$\mathrm{~S} 12$ & $\mathrm{~S} 6$ & .70 & .42 & $\mathrm{~S} 35$ & $\mathrm{~S} 16$ & .58 & 0.41 \\
$\mathrm{~S} 13$ & $\mathrm{~S} 34$ & .24 & .33 & $\mathrm{~S} 36$ & $\mathrm{~S} 32$ & .31 & 0.21 \\
$\mathrm{~S} 14$ & $\mathrm{~S} 9$ & .67 & .23 & $\mathrm{~S} 37$ & $\mathrm{~S} 3$ & .74 & 0.49 \\
$\mathrm{~S} 15$ & $\mathrm{~S} 11$ & .65 & .29 & $\mathrm{~S} 38$ & $\mathrm{~S} 4$ & .72 & 0.37 \\
$\mathrm{~S} 16$ & $\mathrm{~S} 10$ & .67 & .53 & $\mathrm{~S} 39$ & $\mathrm{~S} 5$ & .72 & 0.26 \\
$\mathrm{~S} 18$ & $\mathrm{~S} 12$ & .65 & .46 & $\mathrm{~S} 40$ & $\mathrm{~S} 21$ & .47 & 0.40 \\
$\mathrm{~S} 19$ & $\mathrm{~S} 8$ & .68 & .51 & $\mathrm{~S} 41$ & $\mathrm{~S} 20$ & .50 & 0.43 \\
$\mathrm{~S} 22$ & $\mathrm{~S} 30$ & .31 & .27 & $\mathrm{~S} 42$ & $\mathrm{~S} 14$ & .62 & 0.47 \\
$\mathrm{~S} 23$ & $\mathrm{~S} 26$ & .42 & .52 & $\mathrm{~S} 43$ & $\mathrm{~S} 33$ & .29 & 0.25 \\
$\mathrm{~S} 24$ & $\mathrm{~S} 31$ & .31 & .28 & $\mathrm{~S} 44$ & $\mathrm{~S} 35$ & .24 & 0.26 \\
$\mathrm{~S} 25$ & $\mathrm{~S} 23$ & .45 & .44 & $\mathrm{~S} 45$ & $\mathrm{~S} 36$ & .45 & 0.35 \\
$\mathrm{~S} 26$ & $\mathrm{~S} 7$ & .69 & .40 & $\mathrm{~S} 46$ & $\mathrm{~S} 37$ & .21 & 0.22 \\
$\mathrm{~S} 27$ & $\mathrm{~S} 17$ & .54 & .35 & $\mathrm{~S} 47$ & $\mathrm{~S} 38$ & .60 & 0.32 \\
$\mathrm{~S} 28$ & $\mathrm{~S} 24$ & .45 & .34 & $\mathrm{~S} 48$ & $\mathrm{~S} 39$ & .47 & 0.42 \\
$\mathrm{~S} 29$ & $\mathrm{~S} 19$ & .52 & .57 & $\mathrm{~S} 49$ & $\mathrm{~S} 40$ & .15 & 0.26 \\
\hline
\end{tabular}

Lastly, in the final form of the achievement test, items were ordered according to their difficulty indices from easy to difficult except the matching type question which was stated as the last question in the test. As a result of the item analyses, the distribution of test items across the goals of PMI course was indicated in Table 4.

Table 4. Distribution of Test Items across the Goals of the Course after the Pilot Study

\begin{tabular}{ll}
\hline Goals of the Course & $\begin{array}{l}\text { Item Numbers in the Final } \\
\text { Form }\end{array}$ \\
\hline $\begin{array}{l}\text { 1. Students will be able to understand the basic concepts related to education. } \\
\text { 2. Students will be able to use appropriate principles in different teaching-learning } \\
\text { situations. }\end{array}$ & $\begin{array}{l}29,36,37,38,39,40 . \\
\text { 3. Students will be able to understand the properties of objectives. }\end{array}$ \\
$\begin{array}{l}\text { 4. Students will be able to use different types of objectives in accordance with } \\
\text { teaching-learning situations. }\end{array}$ & 22 \\
$\begin{array}{l}\text { 5. Students will be able to understand the properties of teaching plans. } \\
\text { 6. Students will be able to know the properties of teaching-learning theories, }\end{array}$ & 9,11 \\
$\begin{array}{l}\text { approaches, strategies, methods and techniques. } \\
\text { 7. Students will be able to understand the properties of teaching-learning theories, } \\
\text { models and approaches. }\end{array}$ & $30,26,31$ \\
$\begin{array}{l}\text { 8. Students will be able to use appropriate theories, models and approaches for } \\
\text { different teaching-learning conditions. }\end{array}$ & 23 \\
9. Students will be able to understand the properties of teaching strategies. & 7,17 \\
\hline
\end{tabular}


10. Students will be able to use appropriate teaching strategies for different teaching-learning conditions.

11. Students will be able to understand the properties of teaching methods.

12. Students will be able to use appropriate teaching methods for different teaching-learning conditions.

13. Students will be able to understand the properties of teaching techniques.

14. Students will be able to use appropriate teaching techniques for different teaching-learning conditions.

Total Number of Items

\section{4}

$19,15,27,18$

$28,2,16$

$32,3,4,5,21$

$20,14,35$

40

In addition to these, the difficulty indices of the items $(p)$ in the final form of the test were classified in Table 5. As shown in Table 5, the difficulty indices of all items except two items are between 0.20 and 0.80 . In the test, one item is very easy, one item is very difficult, 14 items are of medium difficulty, 14 items are easy and 10 items are difficult.

Table 5. Distribution of Substances by Substance Difficulty Index

\begin{tabular}{|c|c|c|c|}
\hline $\begin{array}{l}\text { Item Difficulty } \\
\text { Indices }\end{array}$ & $\begin{array}{l}\text { Number of } \\
\text { Items }\end{array}$ & Item Numbers & Categories \\
\hline $\mathrm{p}>.80$ & 1 & S1 & Very easy \\
\hline $.60<\mathrm{p}<.79$ & 14 & $\begin{array}{l}\text { S2, S3, S4, S5, S6, S7, S8, S9, S10, S11, S12, S13, S14, } \\
\text { S38 }\end{array}$ & Easy \\
\hline $.40<\mathrm{p}<.59$ & 14 & $\begin{array}{l}\text { S15, S16, S17, S18, S19, S20, S21, S22, S23, S24, S25, } \\
\text { S26, S36, S39 }\end{array}$ & Medium \\
\hline $.20<\mathrm{p}<.39$ & 10 & S27, S28, S29, S30, S31, S32, S33, S34, S35, S37 & Difficult \\
\hline $\mathrm{p}<.19$ & 1 & S40 & $\begin{array}{l}\text { Very } \\
\text { difficult }\end{array}$ \\
\hline Total & 40 & & \\
\hline
\end{tabular}

In Table 6, some of the statistics related to the PMI course achievement test was stated. The developed AT is valid and reliable (see sample items in Appendix A). The developed test contained 40 questions with the mean item difficulty .51 , mean item discrimination value .37 and the $\mathrm{Kr}-20$ reliability coefficient .78.

Table 6. Final Statistics for the Achievement Test

\begin{tabular}{ll}
\hline Number of Items & 40 \\
Number of Participants & 453 \\
Mean & 20.35 \\
Standard Deviation & 6.07 \\
Skewness & .05 \\
Kurtosis & -0.38 \\
Mean Item Difficulty & .51 \\
Mean Item Discrimination & .37 \\
Kr-20 & .78 \\
\hline
\end{tabular}

\section{DISCUSSION AND CONCLUSION}

This study aimed to develop an achievement test in the Principles and Methods of Instruction Course. 14 goals were developed by following the aims of the course as determined by the Council of Higher Education. As a result of the item analyses, the PMI course achievement test was developed which is valid and reliable. The developed test contained 40 questions with the mean item difficulty .51, mean item discrimination value .37 and the $\mathrm{Kr}-20$ reliability coefficient .78 .

In this study, the analyses were conducted using TAP (version 14.7.4) program to determine whether each test items significantly differentiated the mean scores of pre-service teachers in the upper and lower groups. In this way, pre-service teachers who learned the subject or not were able to be determined. A small number of researchers included an analysis program during the achievement test development process. While some of the researchers included 'ITEMAN 3.50' program for item analyses (Can-Şen \& Eryılmaz, 2011; Türky1lmaz, 2016), some of the researchers calculated item statistics by comparing the average of 
27\% lower and upper groups using SPSS (Çardak \& Selvi, 2018; Gültekin, 2016; Yünkül, 2014) and others used excel for the data analysis (Ilhan \& Hoşgören, 2017).

During the achievement test development process, three or four test items were written for each goals of the course. In the literature, it is recommended that at least three items should be written for the sample test for each goals of the course (Özçelik, 2011; Turgut \& Baykul, 2011). In the current study, three or four items were written for each of the 14 goals and a 40-item sample test was prepared and applied to the participants. For this reason, it can be said that the content validity of the test was provided because the remaining items of the sample test reflected each critical behaviors about the PMI course. In the study conducted by Firat-Durdukoca (2013) an 89-item sample PMI course achievement test was prepared but eight items found to be unsuitable after taking expert opinions. However, after item analyses, the final form included 48 items by excluding 33 items from the test. Similarly, the sample achievement test developed about modern physics for the secondary students by Kotluk \& Yayla (2016) included 31 questions; however, after data analyses by excluding 6 items, final form of it included 25 items. In addition, Gültekin (2016) developed a sample achievement test about the PMI course which included 60 items; however, 10 items were excluded from the test after conducting item analyses. Polat (2016) developed a sample achievement test for the PMI course which consisted of 67 items and six items were excluded from the test after taking the opinions of experts. The final form of the achievement test included 43 questions after the item analyses. As a consequence, it can be said that although nine items were removed from the achievement test, the remaining 40 items ensured the content validity of the test because of reflecting each goals about the PMI course.

During the development process of achievement tests for different subjects and courses, a differing number of students or pre-service teachers were included for the pilot studies. For instance, İlhan and Hoşgören (2017) included 125 students for acids and bases subject; Kotluk and Yayla (2016) included 165 secondary students for modern physics; Çam (2006) included 148 students for visual reading test; Demir, Kizilay \& Bektas (2016) included 100 students for $7^{\text {th }}$ grade solutions subject; Fidan (2013) included approximately 300 elementary students for each grade levels of mathematics course and Altunkaya (2016) included 510 undergraduate students for English course. In addition to these, for the PMI course Gültekin (2016) included 260 and Polat (2016) included 309 pre-service teachers. Furthermore, Cardak \& Selvi (2018) conducted two separate pilot applications for item analyses while 381 pre-service teachers participated in the first applications, 113 pre-service teachers participated in the second application. Therefore, it can be said that the number of participants included in the current study is sufficient.

The current achievement test included goals and objectives at the knowledge, comprehension and application levels according to Bloom's Taxonomy. It was thought more appropriate to include open-ended questions or alternative evaluation types to evaluate goals and objectives at the levels of analysis, synthesis and evaluation. The current achievement test included multiple-choice questions as well as a five-item matching type question. In some test development studies only multiple-choice type items were included (Çardak and Selvi, 2018). The achievement test which was developed by Tican (2013) included 44 multiplechoice questions, one matching type question and five open-ended questions. The presence of open-ended questions besides multiple-choice questions may provide an opportunity to assess the goals and objectives at analysis, synthesis and evaluation levels with standard, valid and reliable measurement instruments. Also, Altunkaya (2016) included six true-false and 39 multiple-choice items to determine reading comprehension levels of Turkish learners who learn English as a foreign language.

In this study, a preliminary application of the sample test with a five pre-service teachers were conducted to be able to obtain the opinions of them in terms of clarity and comprehensibility of the test items. While some researchers included both expert and student opinions during the development of sample achievement tests (Altunkaya, 2016; Fırat-Durdukoca, 2013; Ilhan \& Hoşgoren, 2017; Kotluk \& Yayla, 2016), some researchers only consulted experts to ensure the validity of the test (Gültekin, 2016; Tican, 2013; Polat, 2016; Yünkül, 2014). In addition, there are studies that did not specify whether the opinions of experts and students were obtained about sample test before its application (Türky1lmaz, 2016). By including a preliminary application of the sample test, pre-service teachers who represent the participants of the current study were able to present their opinions on issues that the researchers could not think of.

The administration of achievement test's final form can take 40-45 minutes and it can be easily scored so it is a user-friendly measurement and assessment tool. The tests can be used for summative evaluation purposes at the end of the semester since it addresses all semester goals of the PMI course. The test is also a good measurement and assessment tool to examine the knowledge levels of pre-service teachers and their misconceptions about this course in higher education institutions. Moreover, this achievement test can be 
used by researchers who carry out scientific studies about this course and to check the criterion validity of the achievement tests developed by thems or other researchers.

One of the limitations of the study is that item analyses were conducted according to classical test theory conventions. However, besides using classical test theory to develop an achievement test, the item analyses might be conducted using item response theory as well and the obtained item difficulty and discrimination indices could be compared for more accurate results. Moreover, in this study, there is no information about the structure and dimensionality of the achievement test. Future studies by using exploratory factor analysis might present some information about it.

Some implications may be proposed for future studies designed to develop a valid and reliable achievement test to determine student achievement in the PMI course or other courses. First of all, different types of questions such as open-ended can be included besides the multiplechoice and matching type questions. In this way, it can provide an opportunity to measure the goals and objectives at the analysis, synthesis, and evaluation levels which are difficult to measure with multiple-choice items. In addition, in order not to damage the content validity of the achievement test after the item analyses, it may be suggested writing at least three test items for each goals and objectives and a small group of students representing the participants of the study may be asked about their suggestion before the applications of the sample test. 


\section{REFERENCES}

Akhter, N., \& Bahoo, R. (2015). Development of a semi standardized achievement test of education for intermediate level. Journal of Educational Research 18(1), 5-19.

Altunkaya, H. (2016). Yabancı Dil Olarak Türkçe Öğrenenlere Yönelik Okuduğunu Anlama Başarı Testinin Geliştirilmesi. Turkish Studies-International Periodical for the Languages, Literature and History of Turkish or Turkic, 11(3), 113-138. doi: http://dx.doi.org/10.7827/TurkishStudies.9324

Anderson, L. W. (Ed.), Krathwohl, D. R. (Ed.), Airasian, P. W., Cruikshank, K. A., Mayer, R. E., Pintrich, P. R., Raths, J., \& Wittrock, M. C. (2010). Ögrenme öğretim ve değerlendirme ile ilgili bir sinfflama: Bloom'un eğitimin hedefleri ile ilgili sinıflamasinin güncelleştirilmiş biçimi ( $1^{\text {st }}$ ed.). (Translator: Durmuş A. Özcelik., 2010.). Ankara: Pegem Akademi.

Aydede, M. N., Caglayan, Ç., Matyar, F., \& Gulnaz, O. (2006). Fen ve teknoloji öğretmenlerinin kullandıkları öğretim yöntem ve tekniklerine ilişkin görüşlerinin değerlendirilmesi. Çukurova Üniversitesi Eğitim Fakültesi Dergisi, 2(32), 24-34.

Büyüköztürk, Ş., Kılıç-Çakmak, E. K., Akgün, Ö. A., Karadeniz, Ş., \& Demirel, F. (2010). Bilimsel araştırma yöntemleri. Ankara: Pegem Yayınc1lı.

Çam, B. (2006). İlköğretim öğrencilerinin görsel okuma düzeyleri ile okuduğunu anlama, eleş̧irel okuma ve Türkçe dersi akademik başarıları arasındaki ilişki (Doctoral dissertation). Eskişehir Osmangazi University, Eskişehir.

Can-Şen, H. \& Eryılmaz, A. (2011). Bir başarı testi geliştirme çalışması: Basit elektrik devreleri başarı testi geçerlik ve güvenirlik araştırmas1. Journal of Yüzüncü Yll University Faculty of Education, 8(1), 1-39.

Cardak, C. S. \& Selvi, K. (2018). Öğretim ilke ve yöntemleri dersi için bir basari testi geliştirme sureci. Akdeniz Eğitim Araştırmaları Dergisi, 12(26), 379-406. doi: 10.29329/mjer.2018.172.19

Chiatula, V. O. (2015). Integrative pre-service elementary teacher training: The role of interdisciplinary collaborative mathematics. Education Faculty Publications 136(2), 113-122. Retrieved June 12, 2017, from https://eric.ed.gov/?id=EJ1095616

Cochran-Smith, M. (2004). The problem of teacher education. Journal of Teacher Education, 55, 295-299. doi: $10.1177 / 0022487104268057$

Creswell, J. W. (2012). Educational research: Planning, conducting, and evaluating quantitative and qualitative research. Boston: Pearson.

Demir, N., Kızılay, E., \& Bektaş, O. (2016). Development of an achievement test about solutions for $7^{\text {th }}$ graders: A validity and reliability study. Necatibey Faculty of Education Electronic Journal of Science and Mathematics Education, 10(1), 209-237.

Dikici, A., Gundogdu, R., \& Yavuzer Y. (2006). Eğitim fakültesi mezunlarının eğitim bilimleri derslerine ilişkin görüşleri (Niğde üniversitesi örneği). [Opinions of education faculty graduates relating to pedagogy courses (The Sample of Niğde University)]. Milli Eğitim Dergisi, 172, 250-262.

Eret, E. (2013). An assessment of pre-service teacher education in terms of preparing teacher candidates for teaching (Doctoral dissertation). Middle East Technical University, Ankara.

Fidan, E. (2013). İlkokul öğrencileri için matematik dersi sayılar öğrenme alanında başarı testi geliştirilmesi [Development of achievement tests in the number domain of mathematics course for elementary school students] (Master's thesis). Ankara University, Ankara.

Fırat-Durdukoca, Ş. (2013). Dizgeli eğitim ve düzanlatım yöntemleriyle işlenen öğretim uygulamalarının öğretmen adaylarının epistemolojik inanç, ögrenme yaklaşımları, üstbilişsel farkındalık ve akademik başarılarına etkisi. (Doctoral dissertation). İnönü University, Malatya.

Fraenkel, J. R. \& Wallen, N. E. (2009). How to design and evaluate research in education $\left(7^{\text {th }}\right.$ ed.). New York: McGraw Hill.

Gültekin, S. (2016). Eleştirel düşünmeye dayalı ögretim ilke ve yöntemleri dersi program tasarısinin öğrenme ürünlerine etkisi (Doctoral dissertation). Balıkesir University, Balıkesir.

Ilhan, N. \& Hoşgören, G. (2017). Fen bilimleri dersine yönelik yaşam temelli başari testi geliştirilmesi: Asit baz konusu. Fen Bilimleri Öğretimi Dergisi, 5(2), 87-110.

Kahramanoglu, R. (2010). Eğitim fakültelerinde okutulmakta olan öğretmenlik meslek bilgisi derslerinin ögrretmen görüşlerine göre değerlendirilmesi. [The evaluation of courses oriented for teaching skills in education faculties according to teachers' views]. (Master's thesis). Mustafa Kemal University, Hatay.

Kara, F., \& Çelikler, D. (2015). Development of achievement test: Validity andreliability study for achievement test on matter changing. Journal of Education and Practice, 6(24), 21-26.

Kotluk, N. \& Yayla, A. (2016). Yenilenmiş Bloom taksonomisine göre modern fizik başarı testinin geliştirilmesi: Geçerlik ve güvenirlik çalışması. Journal of Yüzüncü Yıl University Faculty of Education, 8(1), 213-231.

KPSS (2012). Public Personnel Selection Examination. [Kamu personel seçme sinavı lisans. Eğitim bilimleri testi.] ÖSYM: Ankara. Retrieved July 12, 2018, from https://dokuman.osym.gov.tr/pdfdokuman/2012/KPSS/Lisans/KPSS1_2012_COS_EGT.pdf

KPSS (2013). Public Personnel Selection Examination. [Kamu personel seçme sinavi lisans. A grubu ve öğretmenlik. Eğitim bilimleri testi.] ÖSYM: Ankara. Retrieved July 12, 2018, from https://dokuman.osym.gov.tr/pdfdokuman/2013/KPSS1/C\%C3\%96S.pdf

KPSS (2014). Public Personnel Selection Examination. [Kamu personel seçme sınavı lisans. Eğitim bilimleri testi.] ÖSYM: Ankara. Retrieved July 12, 2018, from 
https://dokuman.osym.gov.tr/pdfdokuman/2014/KPSS/SINAVSORULARI/2014KPSSALANCOSEgitimBili mleri.pdf

KPSS (2015). Public Personnel Selection Examination.[Kamu personel seçme sinavı lisans. A grubu ve ögretmenlik. Eğitim bilimleri testi.] ÖSYM: Ankara. Retrieved July $12, \quad$ 2018, from https://dokuman.osym.gov.tr/pdfdokuman/2015/KPSS/SINAVSORULARI/2015KPSSALANEgitimBilimleri . $\mathrm{pdf}$

KPSS (2016). Public Personnel Selection Examination. [Kamu personel seçme sinavı lisans. Eğitim bilimleri testi.] ÖSYM: $\quad$ Ankara. $\quad$ Retrieved $\quad$ July $\quad 12, \quad 2018, \quad$ from https://dokuman.osym.gov.tr/pdfdokuman/2016/KPSS/2016KPSSEgitimBilimleri.pdf

KPSS (2017). Public Personnel Selection Examination. [Kamu personel seçme sınavı. A grubu ve ögretmenlik. Ĕ̌̆itim bilimleri testi.] ÖSYM: Ankara. Retrieved July https://dokuman.osym.gov.tr/pdfdokuman/2017/KPSS/EB 23052017.pdf

MEB (2006). Öğretmen mesleği genel yeterlilikleri. Öğretmen Yetiştirme ve Eğitimi Genel Müdürlügü: $\begin{array}{lllll}\text { Ankara. } & \text { Retrieved } & \text { from } & \text { July } & 12,\end{array}$ https://oygm.meb.gov.tr/meb_iys_dosyalar/2017_12/13161921_YYretmenlik_MesleYi_Genel_YETERLY KLERi_onaylanan.pdf

Ozcelik, D. A. (2010). Okullarda ölçme ve değerlendirme: Öğretmen el kitabı (1 $1^{\text {th }}$ ed.). Ankara: Pegem Akademi.

Ozcelik, D. A. (2011). Ölçme ve değerlendirme (4 ${ }^{\text {th }}$ ed.). Ankara: ÖSYM.

Ozturk, Ç. (2004). Ortaöğretim coğrafya öğretmenlerinin öğretim yöntem ve tekniklerini kullanabilme yeterlikleri. Gazi Üniversitesi Kırşehir Ĕ̈itim Fakültesi. 5(2), 75-83.

Pegem Akademi. (2019). KPSS öğretmenlik sınavı hakkında. Retrieved from https://www.pegemakademi.com/kurslar/kpss-ogretmenlik.

Polat, H. (2016). Çeşitli öğrenme ortamlarında sınıf yönetiminin çeşitli değişkenler açısından incelenmesi (Doctoral dissertation). Firat University, Elazı̆̆.

Tan, Ş., Erciyeş, G., Güven, B., ve Kılıç, A. (2007). Öğretim ilke ve yöntemleri. Ankara: PegemA Yayıncılık.

Taskaya, S. M., \& Musta, M. C. (2008). Sınıf öğretmenlerinin Türkçe öğretim yöntemlerine ilişkin görüşleri. [Teachers' opinions on Turkish teaching methods]. Electronic Journal of Social Sciences), 7(25), $240-251$. Retrieved March 26, 2018, from http://dergipark.gov.tr/esosder/issue/6139/82375

Tican, C. (2013). Yansıtıcı düşünmeye dayalı öğretim etkinliklerinin öğretmen adaylarının yansıtıcı düşünme becerilerine, eleştirel düşünme becerilerine, demokratik tutumlarına ve akademik başarılarına etkisi (Doctoral dissertation). Gazi University, Ankara.

Tosun, C., \& Taşkesenligil, Y. (2011). Revize edilmiş Bloom’un taksonomisine göre çözeltiler ve fiziksel özellikleri konusunda başarı testinin geliştirilmesi: Geçerlik ve güvenirlik çalışması [Development of an achievement test about solutions and their physical properties based on bloom's revised taxonomy: validity and reliability.]. Kastamonu Education Journal, 19(2), 499-522.

Turgut, M. F. \& Baykul, Y. (2011). Eğitimde ölçme ve değerlendirme (3 ${ }^{\text {rd }}$ Ed.). Ankara: Pegem Akademi.

Türkyılmaz, A. (2016). Öğrenme stratejileri öğretiminin öğretmen adaylarının akademik başarılarına, öğrenme güdülerine, kullandıkları öğrenme stratejilerine ve yürütücü bilişlerine olan etkisinin belirlenmesi (Doctoral dissertation). Balıkesir University Balıkesir.

Uzunoglu-Yegül, B. (2014, October). Yapılandırmacı yaklaşıma yönelik akademik başarı testi geliştirme çalışması. [Academic success test development study related with constructivist approach]. Paper presented at the ninth International Balkans Education and Science Congress, Edirne, Turkey.

YÖK. (2007). Yüksek Öğretim Kurulu. [The Council Higher Education]. Öğretmen yetiştirme ve eğitim fakülteleri (1982-2007): Öğretmenin üniversitede yetiştirilmesinin değerlendirilmesi. [Teacher training and faculties of education (1982-2007): The evaluation of teacher training in university. Ankara: Yüksek Öğretim Kurulu Yayını.

Yüksel, S. (2013). Öğretmen yetiştirmede hesap verebilirlik bağlamında KPSS sonuçlarının değerlendirilmesi. Hacettepe Üniversitesi Ĕ̈itim Fakültesi Dergisi, Özel Sayı (1), 404-420.

Yünkül, E. (2014). Çoklu ortam tasarım ilkelerine göre hazırlanan öğretim yazılımının başarı ve tutuma etkisi. (Doctoral dissertation). Balıkesir University, Balıkesir. 


\section{APPENDIX}

Sample Items of Principles and Methods of Instruction Course Achievement Test / Öğretim İlke ve Yöntemleri Dersi Testi Örnek Maddeler

Ad Soyad:

Bölüm:

Değerli Öğretmen Adayları,

Bu test iki bölümden oluşmaktadır. Birinci bölümde 35 çoktan seçmeli; ikinci bölümde ise bir eşleştirme sorusu bulunmaktadır. Lütfen tüm soruları cevaplamaya çalışınız. Sınav süresi 45 dakikadır.

Birinci Bölüm: Aşağıdaki soruları okuduktan sonra doğru seçeneği daire içine alarak işaretleyiniz.

1. Aşağıdaki örneklerden hangisi gösterip-yaptırma öğretim yönteminin kullanılabileceği durumlar için uygun bir örnek değildir?

A) Bir müzik öğretmeninin, 23 Nisan'da Zeybek oynamayı öğretmek için hareketin tümünü öğrencilere göstererek ve küçük parçalara bölerek her öğrencinin tekrar etmesini sağladığı durumlarda

B) Aşçılık okulundaki bir öğrencinin uzmanın talimatlarını adım adım izleyip gerekli düzeltmelere göre yemeği yaptı̆̆ durumlarda

C) Tıp fakültesinde yaraya dikiş atmayı öğretmek için öğretim üyesinin bir kadavra üzerinde öncelikle kendisinin nasıl dikiş attığını anlatarak açıklaması sonrasında ise öğrencilerden diğer yaraları dikmelerini istediği durumlarda

D) Bir modacının kumaşı kesmeyi gösterdiği ve ardından öğrencilere verdiği kumaş parçalarını uygun ölçülerde kesmelerini izlediği durumlarda

E) Öğretmenin kaldırma kuvveti ile ilgili bir deneyi yaptığı, öğrencilerin deneyin yapılış aşamalarını dikkatle izleyip not aldığı durumlarda

2. Bir matematik öğretmeni öğrencilerini üç gruba ayırıp farklı küme çeşitlerine girebilecek şarkılar dinleyebilecekleri "cd"ler; farklı küme çeşitleri oluşturmaları için kartonlar ve kümelerin özelliklerini kullanarak bir şiir yazabilecekleri renkli kağıtlar bırakmıştır. Her bir grup tüm masalardaki çalışmaları tamamlamıştır. Bu öğretmen derste aşağıdaki tekniklerden hangisini kullanmaktadır?
A) Köşeleme
B) İstasyon
C) Gösteri
D) Çember
E) Akvaryum

3. Öğretmen, matematik dersinde mutlak değer konusu ile ilgili olarak yaptı̆̆ 1 açıklamalardan sonra, öğrencilerle soru-cevap etkinliği yapmıştır ve Uzungöl, Ağrı Dağı, Van Gölü, Ayder Yaylası gibi yerlerin denizden yükseklik ve derinliklerinin işaretlerle gösterildiği resimli çalışma yaprakları dağıtmıştır. Öğrencilerinden mutlak değer işareti kullanarak gerçek değerlerini göstermelerini istemiştir. Bu etkinlik Gagne'nin öğretim durumları modeline göre aşağıdakilerden hangi aşamaya örnektir?
A) Dikkati çekme
B) Hedeften haberdar etme
C) Ön koşul öğrenmeleri hatırlatma
D) Öğrenmede rehber olma
E) Performansı ortaya çıkarma 